\title{
Communication/Comunicação
}

\section{Characterization of Leishmania infantum species in dogs from the urban area of Cuiabá, State of Mato Grosso, Brazil}

\author{
Caracterização da espécie Leishmania infantum em cães de área urbana de Cuiabá, \\ Estado do Mato Grosso
}

\author{
Bianca De Santis ${ }^{1}$, Elizabeth Gloria Oliveira Barbosa Santos ${ }^{1}$, Elisa Cupolillo ${ }^{2}$, Renato Porrozzi ${ }^{2}$, \\ Amanda dos Santos Cavalcanti' ${ }^{2}$, Bárbara Neves dos Santos ${ }^{2}$, Saulo Teixeira De Moura ${ }^{3}$, Kellen Malhado ${ }^{4}$ \\ and Sergio Augusto Miranda Chaves ${ }^{5}$
}

\begin{abstract}
Introduction: Visceral leishmaniasis presents urban behavior in some Brazilian cities, with domestic dogs as the main infection source. In Cuiabá, MT, canine visceral leishmaniasis was diagnosed and characterized as recommended by the Ministry of Health. Methods: Biological samples from suspected canine carriers were analyzed by the isoenzyme electrophoresis technique. The 6PGDH enzyme and reference strain IOC/L0566 (MHOM/ BR/1975/M2903) of Leishmania (Leishmania) infantum was used as one of the controls. Results: Electrophoresis analysis revealed that the canine isolates belonged to the species $L$. ( $L$.) infantum. Conclusions: The authors emphasize the importance of species characterization, particularly in areas of mixed infection like Cuiabá.
\end{abstract}

Keywords: Canine visceral leishmaniasis. Leishmania infantum. Cuiabá.

\section{RESUMO \\ Introdução: A leishmaniose visceral apresenta comportamento urbano em algumas cidades brasileiras, sendo os cães domésticos as principais fontes de infecção. Em Cuiabá-MT, a leishmaniose visceral canina foi diagnosticada e caracterizada, como recomendação do Ministério da Saúde. Métodos: Amostras biológicas de cães suspeitos foram analisadas por eletroforese de isoenzimas. Foram utilizadas a enzima 6PGDH e a cepa de referência IOC/ L0566 (MHOM/BR/1975/M2903) de Leishmania (Leishmania) infantum, como um dos controles. Resultados: A análise eletroforética revelou que os isolados pertenciam à espécie $L$. (L.) infantum. Conclusões: Os autores ressaltam a importância da caracterização da espécie, principalmente em cidades com infecção mista, como Cuiabá.}

Palavras-chaves: Leishmaniose visceral canina. Leishmania infantum. Cuiabá.

Visceral leishmaniasis (VL) is considered one of the parasitic diseases of greatest impact on public health worldwide. Annually affecting an average of 500,000 people, and endemically ${ }^{1}$ distributed in 65 countries due to the expansion of the area of infection, with a significant increase in the number of cases, VL has become one of the priorities of the group of tropical diseases ${ }^{1,2}$.

1. Laboratório de Zoonoses, Escola Nacional de Saúde Pública Sérgio Arouca, Fundação Oswaldo Cruz, Rio de Janeiro, RJ. 2.Laboratório de Referência Nacional de Tipagem de Leishmania, Fundação Oswaldo Cruz, Rio de Janeiro, RJ. 3. Instituto Federal de Educação, Ciência e Tecnologia de Mato Grosso, São Vicente, MT. 4. Centro de Controle de Zoonoses, Secretaria Municipal de Saúde de Cuiabá, MT. 5. Laboratório de Ecologia, Escola Nacional de Saúde Pública Sérgio Arouca, Fundação Oswaldo Cruz, Rio de Janeiro, RJ.

Address to: Dra. Elizabeth Gloria Oliveira Barbosa dos Santos. Escola Nacional de Saúde Pública/FIOCRUZ. Rua Leopoldo Bulhões 1480, Manguinhos, 21041-210 Rio de Janeiro, RJ, Brazil.

Phone: 5521 2598-2580

e-mail: elizabeth@ensp.fiocruz.br

Received in 19/09/2010

Accepted in 29/01/2011
More than $90 \%$ of VL cases reported in the New World have occurred in Brazil, principally in the northeastern region, where it produces high levels of morbidity. Initially, VL presented a rural character, but has expanded to the urban areas of medium and big cities in the last few decades. This profile modification is mainly observed in the municipal districts of Southeastern and Centralwestern regions of the country, where the VL is urbanized and the domestic $\operatorname{dog}$ (Canis familiaris) is the main infection source ${ }^{2,3}$. It should be highlighted that Cuiabá, the capital of the State of Mato Grosso, is an endemic area for both cutaneous and visceral leishmaniasis.

According to Moura et $\mathrm{al}^{4}$, during the canine survey conducted in the urban area of the City of Cuiabá, $64.5 \%$ seropositivity for leishmaniasis was verified using the indirect immunofluorescence reaction technique (IIR). Of these, $88 \%$ presented high titration (50\% with $1: 640,33.3 \%$ with $1: 320$ and $4.8 \%$ with $1: 160$ ). According to the authors, these results strongly suggested the presence of VL circulating among canines, although species etiologic characterization was not achieved.

The isoenzyme electrophoresis technique permits identification of the type of microorganism isolated. Studies conducted by Cupolillo et $\mathrm{al}^{5}$ classified strains of Leishmania according to species as belonging to the New World and the Old World. Species characterization is fundamental for understanding the biology of the parasite and, although in Brazil the main species is Leishmania infantum $^{5}$, Tolezano et $\mathrm{al}^{6}$ proved that infection in two dogs with clinical VL, from Araçatuba, SP, had been caused by Leishmania amazonensis.

The purpose of the present work was to characterize the etiologic type of CVL present in the captured dogs from Cuiabá, MT. The study was approved by the Animal Use Ethics Committee (CEUA/ FIOCRUZ), under protocol no. 0300/2006.

The Zoonosis Control Center (ZCC) of Cuiabá, MT, selected 44 dogs from urban area of the municipal district, according to clinical, epidemiological and laboratorial criteria compatible with CVL. A convenience sample was used; the goal was to diagnose dogs captured by Cuiabá ZCC with suspected CVL. The dogs were selected based on one of two possibilities: clinical suspicion of and/or seropositivity for CLV, which resided in areas where other serologically positive dogs had been identified or which had records regarding the presence of specific vectors (Lutzomyia longipalpis and Lutzomyia cruzi). All the dogs studied were donated by their owners to the Cuiabá ZCC. 
The dogs were later euthanized according to internal procedures of Cuiabá ZCC: seronegative dogs that were not adopted and all seropositive dogs, in accordance with directives approved by the Brazilian Ministry of Health ${ }^{7}$.

Biological samples (bone marrow and/or spleen and/or liver) were collected from the 44 dogs suspected of having VL or possibly infected by Leishmania sp. Resolution 714, dated June $20^{\text {th }} 2002$, of the Federal Council of Veterinary Medicine (CFMV) was used as the basis of the euthanasia protocol, which outlines the procedures and methods of euthanasia for animals and provides further guidelines ${ }^{8}$. The chosen method was intravenous administration of potassium chloride $(\mathrm{KCl})$, performed by a veterinarian of the Cuiabá ZCC, preceded by general anesthesia achieved with intravenous administration of $25 \mathrm{mg} / \mathrm{kg}$ of sodium thiopental.

Under the effect of the preanesthetic 1\% Acepram (acepromazine $0.1 \mathrm{mg} / \mathrm{kg} \mathrm{IM}, 30$ to $40 \mathrm{~min}$ in advance), some dogs were easily contained for trichotomy, in the area delineated by the tip of the breastbone or the iliac crest, for marrow puncture ${ }^{9,10}$. However, others remained agitated, requiring general anesthesia, with use of $25 \mathrm{mg} / \mathrm{kg}$ of sodium thiopental to achieve the procedure. For the trichotomy, asepsis of the site was performed using detergent, followed by washing with running water, drying and rinsing with $70 \%$ alcohol. After intravenous administration of sodium thiopental anesthetic, the dogs were administered potassium chloride, as described.

The marrow puncture was performed on all 44 dogs, in accordance with procedures adopted by Müller et $\mathrm{al}^{10}$ and Silva ${ }^{11}$. Then trichotomy and asepsis of the area consisting of the abdominal cavity of the dogs followed, for liver and/or spleen puncture. Following incision, sample collection was initiated with consecutive movements insertion and removal of $2 \mathrm{ml}$ of $0.9 \%$ sterile saline. Next, specimens of bone marrow, liver and spleen were transferred aseptically, in phosphate-buffered saline containing gentamicin $(40 \mathrm{~g} / \mathrm{mL})$, and inoculated directly into tubes of NNN blood-agar medium containing an overlay of Schneider's Drosophila medium (Sigma, St. Louis, MO), supplemented with heat-inactivated $\left(60^{\circ} \mathrm{C}\right.$ for $20 \mathrm{~min}$ ) fetal bovine serum (FBS) and incubated at $25^{\circ} \mathrm{C}$. Parasites isolated from primary culture were transferred to flasks of Schneider's medium containing $20 \%$ FBS and gentamicin $(40 \mathrm{~g} / \mathrm{mL})$ at the same temperature. Promastigotes were grown in culture medium and were used for identification by isoenzyme analysis.

All of the cultures in vitro were expanded to obtain sufficient parasite mass to achieve biochemical characterization. From the cultures in vitro, in NNN and Schneider's medium, using biological samples from the 44 dogs studied, Leishmania sp growth was observed in 16 samples from 8 dogs: 9 bone marrow, 4 liver aspirate and 3 spleen aspirate.

Isoenzymatic characterization was achieved in 9 samples from 5 canines. The tests followed a previously described protocol by Cupolillo et $\mathrm{al}^{5}$ and the enzymes tested were: 6PGDH (6-phosphogluco-dehydrogenase, E.C. 1.1.1.43), G6PDH (glucose-6-phosphate dehydrogenase, E.C.1.1.1.43) and NH (nucleoside hydrolase, E.C.3.2.2.1). The following strains were used as references for comparison with the electrophoretic profiles obtained: IOC/L0566 (MHOM/BR/1975/M2903) Leishmania (Viannia) braziliensis; IOC/L0575 (IFLA/BR/1967/PH8) Leishmania (Leishmania) amazonensis; IOC/L0579 (MHOM/BR/1974/PP75) Leishmania (Leishmania) infantum.
Analysis of the results proved that the samples of marrow, liver and spleen puncture from dogs suspected of carrying VL captured in the urban area of Cuiabá were infected with the species L. (L.) infantum, as demonstrated when comparing by the isoenzymatic profiles to the reference strain IOC/L0579 (MHOM/BR/1974/ PP75) (Figure 1).

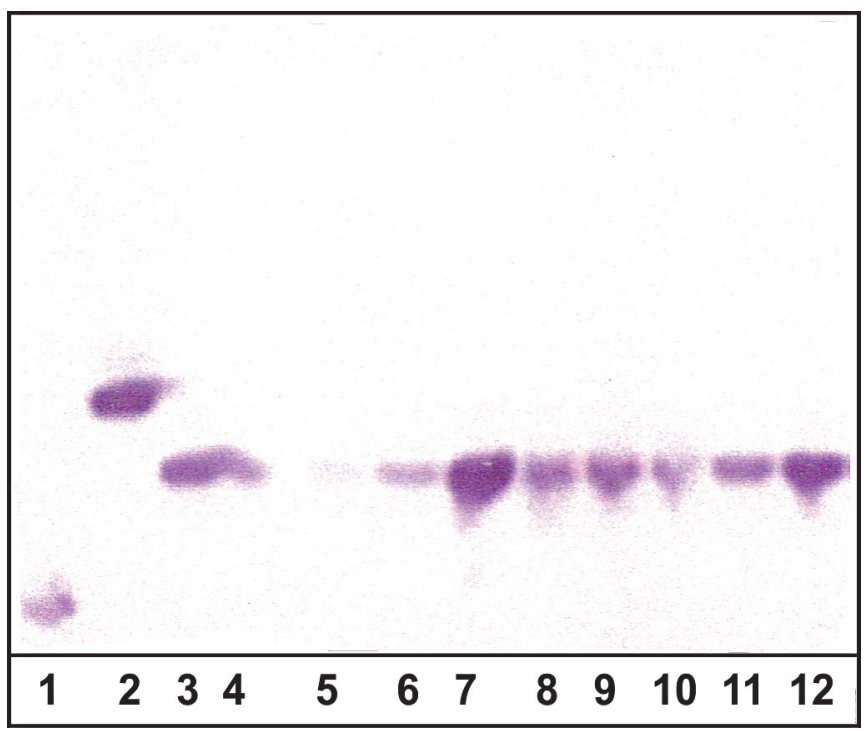

FIGURE 1 - 6PGDH Isoenzymatic profile in agarose gel.

1: IOC/L0566 (MHOM/BR/1975/M2903) Leishmania (Viannia) braziliensis, 2: IOC/L0575 (IFLA/BR/1967/PH8) Leishmania (Leishmania) amazonensis, 3: IOC/L0579 (MHOM/BR/1974/PP75) Leishmania (Leishmania) infantum, 4 and 8: aspirate spleen samples, 5 and 7: samples of liver aspirate, 6, 9, 10, 11 and 12: samples of bone marrow puncture.

CVL is presented as a progressive disease that is often slow and has an insidious onset. When infected, dogs can exhibit a variety of moderate to severe clinical signs or can be asymptomatic, thus contributing as a principal source of infection in urban areas. In a recent seroepidemiological survey for leishmaniasis in dogs domiciled in the urban area of Cuiabá, prevalence of $3.4 \%$ positivity ${ }^{12}$ was determined, with simultaneous cases of $\mathrm{VL}$ and tegumentary leishmaniasis registered in the municipal district ${ }^{13}$.

Programmed actions for the control of CVL include actively searching for symptomatic dogs to apply parasitological exams and to confirm the identification of the Leishmania ${ }^{7}$ species. In a study involving 7 sylvan dogs maintained in captivity in the State of Mato Grosso, the presence of the species L. (L.) infantum chagasi was identified in all of them using the polymerase chain reaction restriction fragment length polymorphism (PCR-RFLP) technique ${ }^{14}$.

In the present study, the isoenzyme electrophoresis technique was performed to characterize the Leishmania species. In different clinical samples of dogs selected by the Cuiabá ZCC that presented clinical, epidemiological and laboratorial evidence compatible with VL, the species responsible was confirmed as L. (L.) infantum. Its taxonomy was in agreement with the law of priority for the classification of microorganisms ${ }^{15}$.

The importance of Leishmania species identification in studies involving domestic and sylvan reservoirs should be highlighted, particularly in areas of mixed infection, with the presence of sympatric species, as occurs in Cuiabá, MT, Brazil. 
CONFLICT OF INTEREST

The authors declare that there are no conflicts of interest.

\section{FINANCIAL SUPPORT}

National Council for Scientific and Technological Development (CNPq).

\section{REFERENCES}

1. World Health Organization. Tropical Disease Research. Strategic Direction for Research - Leishmaniasis; 2004. [cite 2008 June 20]. Available from: http:// www.who.int/tdr/diseases/leish/direction.htm/.

2. Gontijo CMF, Melo MN. Leishmaniose Visceral no Brasil: quadro atual, desafios e perspectivas. Rev Bras Epidemiol 2004; 7:338-349.

3. World Health Organization. Zoonoses and Veterinary Public Health Leishmaniasis. Programmes and Projects; 2008. [cited 2008 June 20]. Available from: http://www.who.int/zoonoses/diseases/leishmaniasis/en/.

4. Moura ST, Fernandes CGN, Pandolpho VC, Silva RR. Diagnóstico de leishmaniose canina na área urbana do município de CUIABA, estado de Mato Grosso, Brasil. Braz J Vet Res Animal Sci 1999; 36:101-102.

5. Cupolillo E, Grimaldi G, Momen H. A general classification of New World Leishmania using numerical zymotaxonomy. Am J Trop Med Hyg 1994; 50:296-311.

6. Tolezano JE, Uliam SRB, Tanaguchi HH, Araújo MFL, Barbosa JAR, Barbosa JER, et al. The first records of Leismania (Leismania) amazonensis in dogs (Canis familiaris) diagnosed clinically as having canine visceral leishmaniasis from Araçatuba county, São Paulo state, Brazil. Vet Parasitol 2007; 41:280-284.

7. Ministério da Saúde. Manual de Vigilância e Controle da Leishmaniose Visceral. $1^{\text {st }}$ ed. Brasília: Editora do Ministério da Saúde; 2006.

8. Conselho Federal de Medicina Veterinária. Resolução no 714 . Dispõe sobre procedimentos e métodos de eutanásia em animais, e dá outras providências; June 20, 2002.

9. Olsson DC, Pippi NL, Martins DB, Tognoli GK, Junior EBS, Müller DC, et al Colheita de medulla óssea em cães: modelo para obtenção da fração total de células mononucleares. Ciência Rural 2008; 38:56-59.

10. Müller DCM, Pippi NL, Basso PC, Olsson DC, Junior EBS, Guerra ACO. Técnicas e sítios de coleta de medula óssea em cães e gatos. Ciência Rural 2009; 39:2243-2251.

11. Silva ES. Leishmaniose visceral canina na região metropolitana de Belo Horizonte, Minas Gerais - Brasil. Diagnóstico, aspectos clínicos e caracterização de amostras de Leishmania. [Dissertation]. [Belo Horizonte]: Centro de Pesquisas René Rachou. Fundação Oswaldo Cruz; 1997. 153 p.

12. Almeida ABPF, Faria RP, Pimentel MFA, Dahroug MAA, Turbino NCMR, Souza VRF. Inquérito soroepidemiológico de leishmaniose canina em áreas endêmicas de CUIABÁ, estado de Mato Grosso. Rev Soc Bras Med Trop 2009; 42:156-159.

13. Só Notícias Web Page [Internet]. Rondonópolis e CUIABÁ concentram 87\% dos casos de leishmaniose em MT. [cited 2010 June 20]. Available from: www. sonoticias.com.br/.

14. Souza NP, Almeida ABPF, Freitas TPV, Paz RCR, Dutra V, Nakazato L, et al. Leishmania (Leishmania) infantum chagasi em canídeos silvestres mantidos em cativeiro, no estado de Mato Grosso. Rev Soc Bras Med Trop 2010; 43:333-335.

15. Dantas-Torres F. Leishmania infantum versus Leishmania chagasi: do not forget the law of priority. Mem Inst Oswaldo Cruz 2006; 101:117-118. 